\title{
Bonding of Amalgam Filling to Tooth Cavity with Adhesive Resin
}

\author{
Judit VARGA*, Hideo MATSUMURA** and Eiichi MASUHARA** \\ *Second Department of Prosthodontics, School of Dentistry, Tokyo Medical and Dental University, 1-5 \\ -45 , Yushima, Bunkyo-ku, Tokyo 113 \\ **Division of Organic Materials, Institute for Medical and Dental Engineering, Tokyo Medical and Dental \\ University, 2-3-10, Kanda-Surugadai, Chiyoda-ku, Tokyo 101, Japan
}

Received on April 3, 1986

Accepted on November 5, 1986

The effects of some adhesives on the bonding of amalgam filling to tooth substance were studied. The bonding agents were 4-META resin with adhesive ability derived from the acid anhydride functional group and PANAVIA EX, a composite type adhesive. The sealing and the bonding effects were measured using the dye penetration and shear tests. Both of the adhesive materials had an excellent ability to seal the leakage between the amalgam and the tooth substance.

Key words: Amalgam, Adhesion, 4-META/MMA-TBB resin

\section{INTRODUCTION}

Amalgams are often used to fill posterior teeth. However, their lack of adhesion to the tooth substance is considered to be the cause of marginal fractures, marginal leakage and finally secondary caries ${ }^{1,2)}$. If the marginal amalgam can adhere to the prepared cavity, marginal leakage can be prevented and moreover the occurence of marginal fracture and secondary caries can also be prevented. The authors examined the adhesive conditions of amalgam to human enamel and the effect of marginal sealing using two types of adhesive resins.

\section{MATERIALS AND METHODS}

\section{Teeth}

The healthy humar teeth consisted of 10 upper central incisors, 10 premolars and 15 molars were used. After their extraction the teeth were refrigerated in physiological saline until use.

2. Amalgam

The amalgam used was the single capsule form of "Shofu Spherical D type"* amalgam, which was mixed according to the manufacturer's instruction for 11 seconds with an amalgam mixer.

\section{Adhesives}

The adhesives used were 4-META/MMA-TBB resin and PANAVIA EX. The initiator of the 4-META type resin was tri- $n$-butylborane and the powder component was polymethyl methacrylate. As the liquid component methyl methacrylate to which had been added $5 \mathrm{wt} \%$

* Shofu Inc., Kyoto, Japan 
4-META prepared by Takeyama's method was used ${ }^{3)}$. (An adhesive of the same component "Super-Bond C \& B"** is on the market.) PANAVIA EX was used as originally produced by its manufacturer***.

4. Dye penetration test

For this test molars and premolars were used. The cavity preparation was Class I cavity without bevel. Before the cavity preparation the roots of the teeth were covered with self-curing resin and 4-META resin, only enamel part of the teeth was exposed. After preparation, the cavity was washed with ethanol, dried up and then was filled with amalgam. Five types of samples were prepared. 1) After the preparation, the cavity was cleaned, dried and filled with amalgam. 2) Before amalgam filling 5 pieces of samples were lined with 4-META resin without etching. 3) The other 5 pieces were lined with PANAVIA EX also without etching. In the cases mentioned above, the teeth used were molars. 4) From the premolars 5 pieces had the cavity surface as whole etched for $30 \mathrm{~s}$ with $65 \% \mathrm{H}_{3} \mathrm{PO}_{4}$ aq. and were washed with water for $5 \mathrm{~min}$, and then were dried up and lined with 4-META resin. 5) On the other 5 pieces of the test-pieces, the etching treatment was carried out for $60 \mathrm{~s}$ with $40 \% \mathrm{H}_{3} \mathrm{PO}_{4}$ aq. After etching here also, the samples were washed with water for $5 \mathrm{~min}$, dried up and lined with PANAVIA EX.

The 4-META resin was applied by a brush on technique, PANAVIA EX was mixed according to the manufacturer's instruction. The so prepared samples were filled with amalgam. The finished samples were kept at room temperature for 2 hours and then were incubated in a fuchsin solution at $37^{\circ} \mathrm{C}$ for 1 day. Then they were polished, finished and were kept once more in the same condition for a week. After this treatment the teeth were cut in slices and the penetration of the dye was observed.

5. Shear adhesive strength test

The buccal surface of an incisor was polished to a plane with emery paper \#220. Five of the 10 pieces were inserted into hard gypsum and the other 5 pieces were inserted into self-curing resin according to the duration of water-soaking. The inserted tooth surface was polished once more with emery paper \# 400 and after polishing, it was etched with $65 \%$ $\mathrm{H}_{3} \mathrm{PO}_{4}$ aq. for $30 \mathrm{~s}$. The etched surface was washed with water for $5 \mathrm{~min}$, then dried and set up with tape which had a circular hole $5 \mathrm{~mm}$ in diameter and $50 \mu \mathrm{m}$ in thickness to determine the area of the adhesive. The adhesive was applied by brushing and the amalgam was applied on the lined surface with the help of a Teflon matrix. The finished samples were kept at room temperature for 24 hours and then were dipped in water and incubated for 1 day and for 1 month at $37^{\circ} \mathrm{C}$. After the incubation shear adhesive strength were measured (Fig. 6).

\section{RESULTS}

1. Dye penetration test

Figures 1-5 show the photos taken on the slices of the teeth after the penetration test and Table 1 shows the results achieved in this test.

1) Non-etched, non adhesive lined samples

** Sun Medical Co., Ltd., Kyoto, Japan

*** Kuraray Co., Ltd., Kurashiki, Japan 
Table 1 Summary of data of dye penetration test

\begin{tabular}{|c|c|c|c|c|c|}
\hline \multirow{2}{*}{$\begin{array}{l}\text { Condition of amalgam } \\
\text { filling }\end{array}$} & Adhesive & \multicolumn{2}{|c|}{ Number of cases } & & \multirow[t]{2}{*}{ Total } \\
\hline & Depth of dye penetration & $0.1-0.5 \mathrm{~mm}$ & $0.5^{-1 \mathrm{~mm}}$ & more than $1 \mathrm{~mm}$ & \\
\hline Non-etched, non-lined cavity & None & 1 & 2 & 2 & $5 / 5$ \\
\hline \multirow{2}{*}{$\begin{array}{l}\text { Adhesive lining on non-etched } \\
\text { cavity }\end{array}$} & 4-META/MMA-TBB & 1 & 0 & 0 & $1 / 5$ \\
\hline & PANAVIA EX & 0 & 0 & 0 & $0 / 5$ \\
\hline \multirow{2}{*}{$\begin{array}{l}\text { Adhesive lining on etched } \\
\text { cavity }\end{array}$} & 4-META/MMA-TBB & 0 & 0 & 0 & $0 / 5$ \\
\hline & PANAVIA EX & 0 & 0 & 0 & $0 / 5$ \\
\hline
\end{tabular}

In each of the samples, dye penetration is appreciable, but the depth and the intensity of the shade of the coloration are not equal. The dye penetration involves all of the walls of the cavity, but on the base a colored layer is also visible. Moreover in many of the samples, the deepest coloration was percepted (Fig. 1a-e).

2) and 3) Non-etched adhesive lined samples

On these samples, which were lined with PANAVIA EX, dye penetration was not shown (Fig. 2). One of the samples lined with 4-META resin shows slight dye penetration involving one of the walls of the cavity. The depth of the coloration was less than $0.1 \mathrm{~mm}$ (Fig. 3).

4) and 5) Etched, adhesive lined samples

Both in the cases of 4-META resin and PANAVIA EX, dye penetration was not visible anywhere (Figs. 4-5)

2. Shear adhesive strength test

1) Samples dipped in water for 1 day

The surface gave the typical shape of cohesive failure of the adhesive. The rest of the adhesive resin was perceptable both on the tooth surface and the sheared amalgam.

2) Samples dipped in water for 1 month

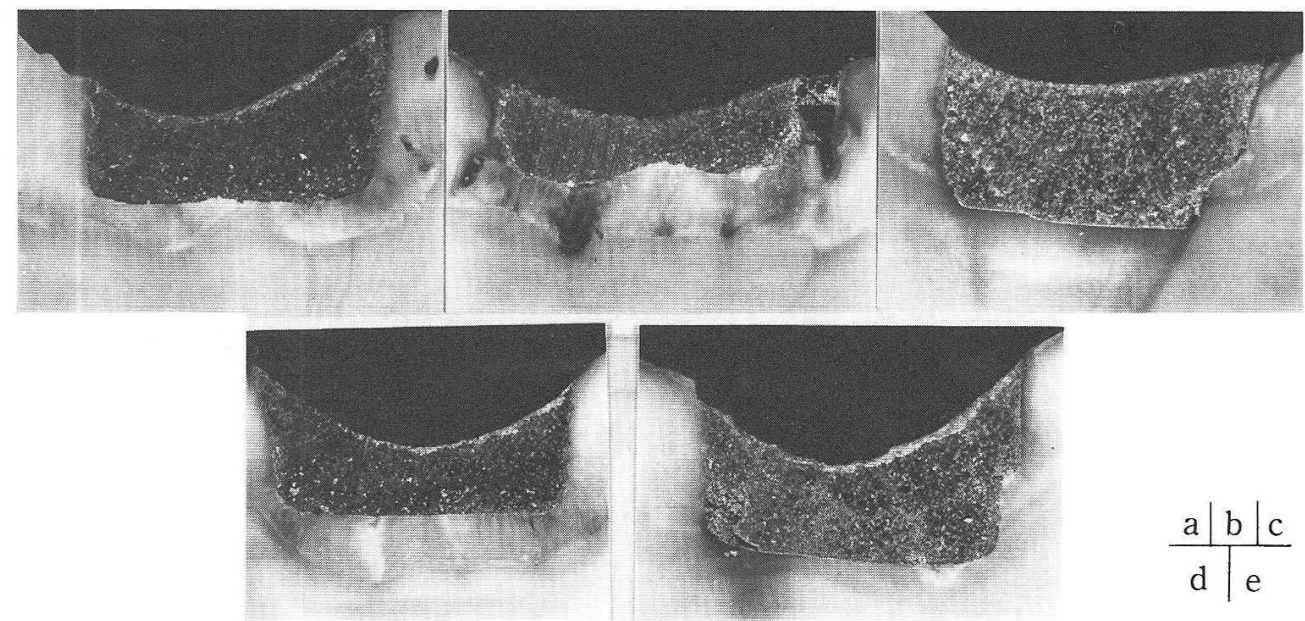

Fig. 1 Shape of the sliced human molar teeth filled with amalgam in non-etched, non-adhesive lined condition after soaking in fuchsin solution for 7 days. Strong dye penetration is seen around the filling in the enamel and also the dentin. 

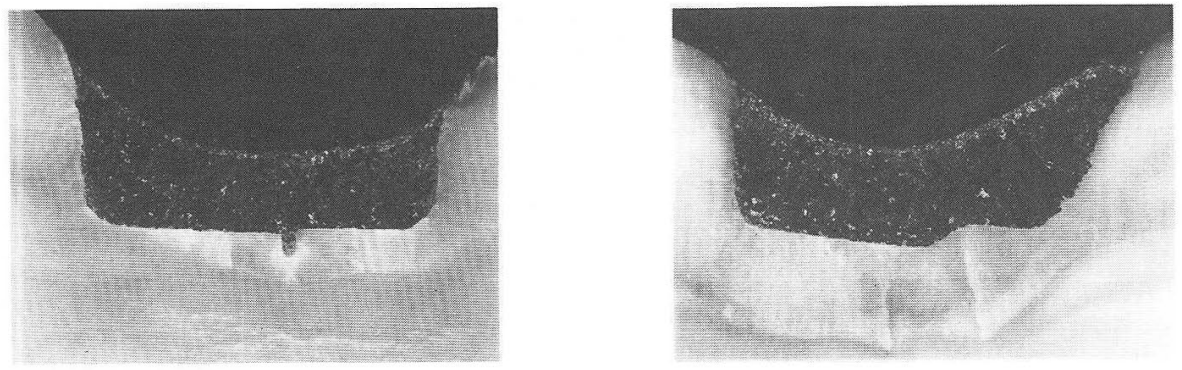

Fig. 2 Shape of the slice of non-etched, lined with PANAVIA EX and amalgam filled human molar tooth. None of the samples show dye penetration.

Fig. 3 Shape of the slice of amalgam filled human molar tooth in non-etched, 4. META/MMA-TBB resin lined condition. Out of the five samples only this one shows a little dye penetration.
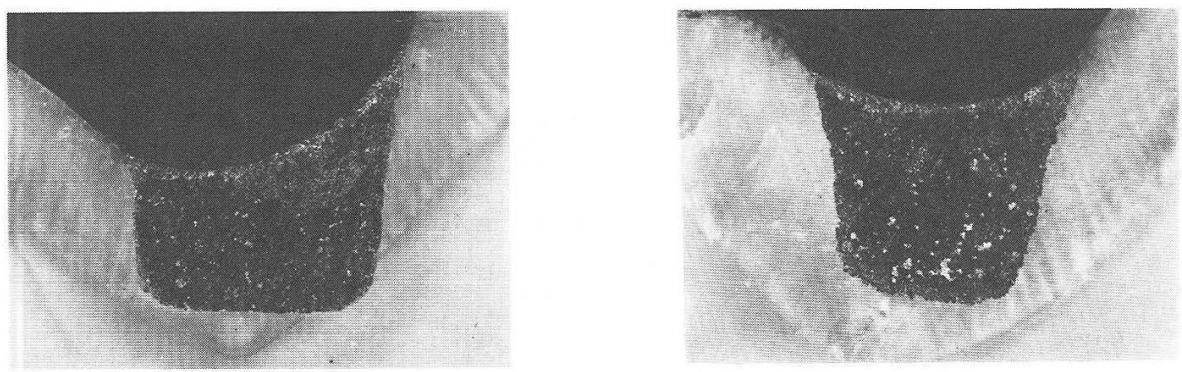

Fig. 4 Shape of the slice of amalgam filled human premolar tooth after etching the cavity walls for $30 \mathrm{~s}$ with $65 \% \mathrm{H}_{3} \mathrm{PO}_{4}$ aq. and lining with 4-META/MMA-TBB resin. None of the samples show dye penetration.

Fig. 5 Shape of the slice of amalgam filled human premolar tooth, for $60 \mathrm{~s}$ with $40 \%$ $\mathrm{H}_{3} \mathrm{PO}_{4}$ aq. etched, PANAVIA EX lined condition. Dye penetration is not seen.

The shape was the same as in the case of the 1-day sample, but here, on the tooth surface, in some places the rest of the amalgam was also visible.

Table 2 is the record of the results of this test. Figure 7 is a photo of the sheared surface of the tooth and the amalgam.

\section{DISCUSSION}

In the case of non-lined samples, no matter how carefully the filling treatment was carried out, after a short time of water-soaking a remarkable penetration of the fuchsin had already occured. As is understandable from the photos of this state, where the coloration is visible on all of the walls of the cavity, despite the polishing and the finishing of the filling, 


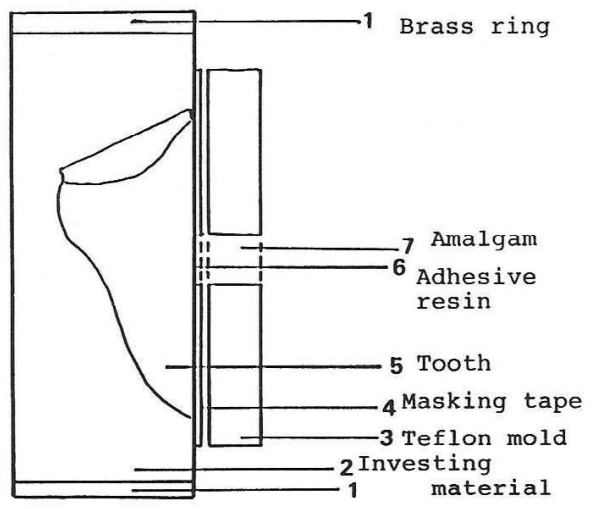

a

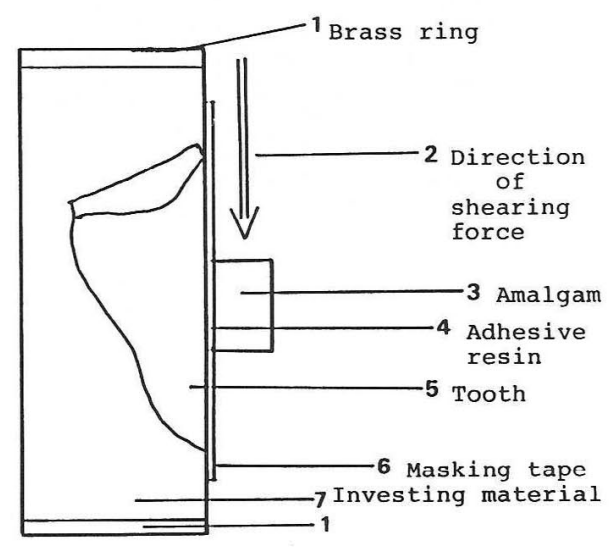

Fig. 6 Method of measuring the shear adhesive strength.

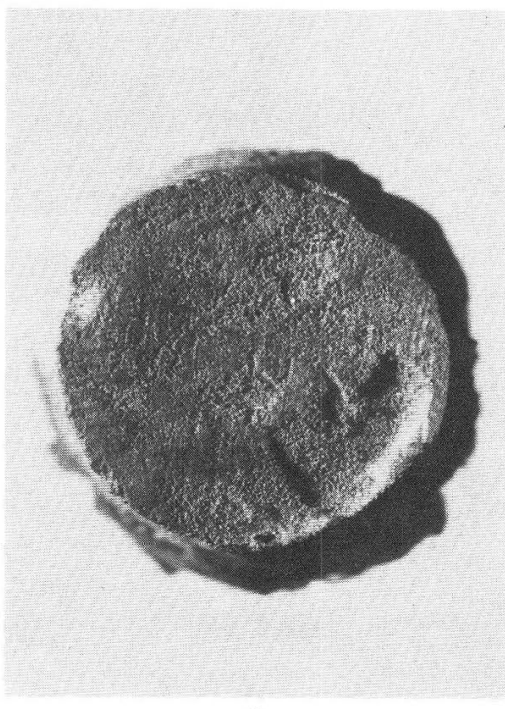

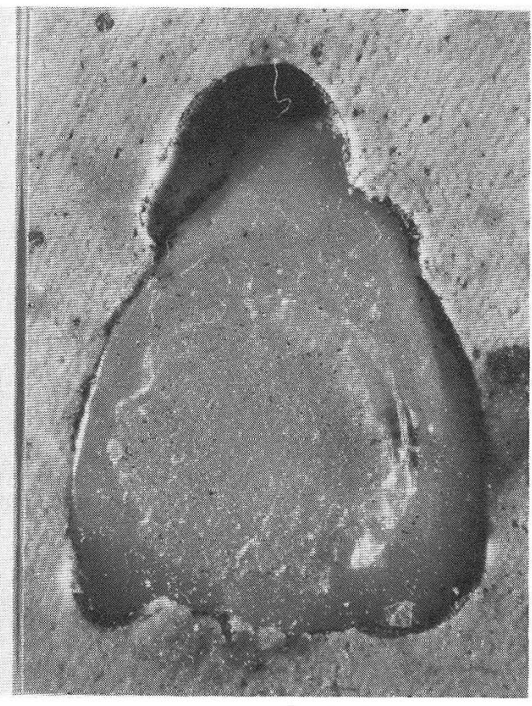

b

Fig. 7 Shape of sheared surface of one of the samples soaked in in water at $37^{\circ} \mathrm{C}$ for 1 month.

a. A typical case of cohesive failure.

b. The rest of the adherend amalgam is visible on the tooth surface.

the microleakage between the filling and the tooth substance does not cease.

When 4-META resin was applied in a non-etched, lined case, one of the samples had visible dye penetration in a minimal quantity. Owing to the etching procedure the enamel surface became rough. The unevenness of the surface gave mechanical retention to the 
Table 2 Shear adhesive strength between etched human enamel and amalgam by 4-META/MMA-TBB resin

\begin{tabular}{lc}
\multicolumn{1}{c}{ Method } & Shear adhesive strength (MPa) \\
\hline $\begin{array}{l}\text { Non-teched, non-lined } \\
\text { dry state }\end{array}$ & 0 \\
$\begin{array}{l}\text { Etched, lined and } \\
\text { soaked in water for } 1 \text { day }\end{array}$ & $13.4 \pm 6.0$ \\
$\begin{array}{l}\text { Etched, lined and } \\
\text { soaked in water for } 1 \text { month }\end{array}$ & $17.7 \pm 4.7$ \\
\hline
\end{tabular}

Mean value of 5 samples \pm standard daviation

adhesive, and it also retarded and ultimately prevented the penetration of water. Because of the grinding procedure some smear which can not be cleaned up with the water cleaning or alcohol-cleaning always remains on the surface. For this reason in a non-etched state the adhesive does not invade into the prism nor does it become mechanically anchored and this is considered as one of the causes of dye penetration. The fact that 4-META is not such a good water-proofing agent can be considered as another cause. However, the fact that only one of the cases was colored can explain why the adhesive fills up the gap between the amalgam and the tooth substance very well. Nevertheless how long this type of adhesion will last could not yet be determined.

For PANAVIA EX the adhesive strength obtained during the long-term thermal cycle test did not show a marked tendency to decrease as the 4-META resin ${ }^{4}$. The lower water absorption characteristic of PANAVIA EX may be the the reason for this and this along with the time factor explains why no dye penetration exists on the PANAVIA EX lined samples.

Both 4-META resin and PANAVIA EX have adhesive bonding effects in connection with etched human enamel and non-precious alloys. This explains why coloration did not occur when the tooth surface was previously cured by etching. However, no matter how excellent the adhesive strength is, PANAVIA EX must not be used deeper than enamel caries. This is because the low viscosity of the material results in its flowing out in every direction and contact with dentin can not be prevented, which is not acceptable for the pulp especially in young patients.

Shear adhesive strength test was carried out only in connection with 4-META resin. For both non-etched and etched enamel surface, if no retention has been prepared, the filled amalgam can be pushed down with the bare hand, because the amalgam has no adhesive ability and the unevenness caused by etching does not have enough mechanical retentive force to prevent failure. When 4-META resin had been applied before the amalgam filling, the force with which the adhesive connects the amalgam to the enamel should be great. Table 2 shows that this force is comparatively high and that it does not decrease even after water-soaking for 1 month.

\section{CONCLUSION}

The present experiments show that by using some kind of adhesive the microleakage of the amalgam filling can be decreased. In this case the same effect as played by the bonding 
agents of composite resin filling can be obtained. This sealing effect can be obtained in the non-etched state of enamel also, but how long this type maintains adhesive durability can not be decided. It seems that in this condition the adhesion is not permanent.

Because PANAVIA EX contains a phosphate type functional monomer, it can adhere with amalgam very well. However, by the effect of compression, PANAVIA EX will flow away and this is considered as a fault for adhesion.

Both the dye penetration test and shear adhesive test make clear that the 4-META/ MMA-TBB resin is a good material for lining the amalgam filling and for this reason can decrease the microleakage. This sealing effect of 4-META resin originated from the particular ability to adhere with each of the components of amalgam as well as that it can adhere with all the substances of the tooth as well.

\section{REFERENCES}

1) Wakumoto, S., Itoh, K. and Katoh, H. : Clinical observation of posterior restoration-marginal integrity of composite in comparison with amalgam, Nippon Dental Review (514) : 66-74, 1985. (in Japanese)

2) Gottlieb, E. W., Retief, D. H. and Bradley, E. L.: Microleakage of conventional and high-copper amalgam restoration, $J$ Prosthet Dent 53 (3) : 355-361, 1985.

3) Takeyama, M., Kash:buchi, S., Nakabayashi, N. and Masuhara, E.: Studies on dental self-curing resins (17) Adhesion of PMMA with bovin enamel or dental alloys, $J$ Japan Soc Dent Appar Mat 19 (47) : 179-185, 1978. (ir. Japanese)

4) Yamashita, A., Kondo. Y. and Fujita, M. : Adhesive strength of adhesive resin PANAVIA EX to dental alloys, Part 1., Adhesive strength of Ni-Cr alloys, J Japan Prosth Dent 28 (4) : 587-598, 1984. (in Japanese) 


\title{
本号掲載論文の和文抄録
}

\author{
熱衝撃試験による金属焼付陶材中の残留応力の評価 \\ 浅岡憲三，桑山則彦 \\ 徳島大学茵学部茵科理工学講座
}

金属焼付陶材の熱衝撃試験をコンピュータシミュレー ションした。すなわち, 初めに 3 次元熱伝導有限要素法 を利用して陶材中の温度分布を求め, その結果をもとに 梁の理論から試験片内の内部応力を計算した。シミュ レーションは陶材, 陶材一オペーク陶材, 陶材ーオペー ク陶材一合金の 3 種の試料について試みた。そして, 板 厚, 熱膨張係数, 焼き入れ温度とTransient stress との 関係について調べ, 以下の結論を得た。 $\alpha_{\mathrm{m}}($ 金属 $)>\alpha_{\mathrm{p}}$ (陶材) の場合, $\alpha_{\mathrm{m}}=\alpha_{\mathrm{p}}$ の場合よりも 陶材表面の応力は高く, 界面での応力は低くなる。また, $\alpha_{\mathrm{m}}<\alpha_{\mathrm{p}}$ の場合には陶材表面の応力は低くなるが, 界面で の応力は高くなる。金属焼付陶材の界面破壊を防ぐには $\alpha_{\mathrm{p}}-\alpha_{\mathrm{m}}$ が $2 \times 10^{-6 \circ} \mathrm{C}^{-1}$ より小さくなくてはならない。

熱膨張係数の異なる 3 種の合金に同じ陶材を焼き付 け，熱衝撃試験を試みた結果はシミュレーションの結果 と良く一致した。

接着性レジンによるアマルガムの窩洞への結合に関する研究

$$
\begin{gathered}
\text { バルガ・ユディト*, 松村英雄**, 増原英一** } \\
\text { *東京医科歯科大学蔝学部第二歯科補経学教室 } \\
\text { **東京医科歯科大学医用器材研究所有機材料部門 }
\end{gathered}
$$

アマルガム充填の際の辺縁封鎖性の向上や破折防止の ための基礎的研究として, 接着性レジンを窩壁に塗布し てから、アマルガムを充填する術式について検討した。 接着材としては酸無水物系モノマー, 4-META を含む MMA-TBB系レジン，および，リン酸エステル系モ， マーを含むパナビア EX を使用した。これらのレジンを 窝壁に塗布してからアマルガムを充填し, 辺縁の漏洩防
止効果と接着強さを測定した。その結果, 接着性レジン を塗布してからアマルガムを充填すると辺縁封鎖に対し 有効であることが明らかになった。また，エナメル質を 酸処理した後，4-META-MMA-TBB 系レジンを塗布 し,アマルガムを充填した場合, 水中浸漬 1 カ月後でも 高い接着強さが得られた。

各種コンポジットレジンとエナメル質の擦り合わせ摩耗に関する研究 甲斐真貴子*，佐藤淳子*，佐藤尚毅*，新谷英章*, 藤岡道治**

*広島大学歯学部歯科保存学第一講座

各種コンポジットレジン (P-10, Clearfil Posterior, Clearfil F II, Palfique, Microjar, Microrest AP, Silar, P-30) と牛歯エナメル質を連続往復水平運動型摩耗試験 機を応用し，100,000 回の擦り合わせ摩耗試験を行うと ともに, 各種コンポジットレジンの諸性質 (フィラー含 有量, ヌープ硬度, 圧縮強度, 弾性率) を調へ, 擦り合
**広島大学歯学部歯科補緅学第一講座

わせ摩耗との関連性を検索した。

各種レジンの摩耗量は MFR 群に少なく, 他のレジン 間とに有意差が認められた $(\mathrm{p}<0.01)$ 。Microrest AP と Silarはほとんど摩耗されなかった。

レジンのフィラー含有量が多く, 硬度が高く, さらに 弾性率の高いレジン程, その摩耗量が多くなった。 